\title{
Effects of Compost on Nematode Pratylenchus sp. (Tylenchida: Pratylenchidae) Population in
} Patchouli

\author{
Cecep Subarjah $^{1,2 *}$, Toto Himawan ${ }^{2}$, Retno Dyah Puspitarini ${ }^{2}$ \\ ${ }^{1}$ Directorate General of Estate, Ministry of Agriculture, Jakarta, Indonesia \\ ${ }^{2}$ Faculty of Agriculture, Brawijaya University, Malang, Indonesia
}

\begin{abstract}
Patchouli is seen as one of the most important export commodities in Indonesia. The presence of parasitic nematode Pratylenchus sp. creates a barrier to plant cultivation. Increasing organic content in soil by applying compost in the plantation is one of approaches in controlling the nematode. This research was mainly aimed to study the effects of compost fertilization on the population growth of nematode Pratylenchus sp. and yields on patchouli. These research used a Completely Randomised Design (CRD) consisting of 12 treatments with three replicates. Selected plant was inoculated with nematodes with the following initial population: 100, 200, 300, 400, and 500 nematodes in soil with and without compost. The plant with no inoculation was used as control. The result of the research confirmed that the addition of compost was capable of suppressing the population of nematode Pratylenchus sp. as much as $58.93-67.31 \%$ and $40.74-59.19 \%$ in root and in soil of each treatment, respectively. Compost applied in each treatment positively affected the increasing amount of Patchouli oil yielded, and it could also reduce the loss as much as $18.34-43.36 \%$. Trichoderma sp. was found to be dominant in compost in the treatment with its population of $2.1 \times 10^{4} \mathrm{propogul} / \mathrm{g}$.
\end{abstract}

Keywords: Organic matters, patchouli, plant-parasitic nematode, Trichoderma sp.

\section{INTRODUCTION}

Patchouli oil serves as basic, secondary, and fixative ingredients commonly used in perfumes, cosmetics, foods and drinks [1]. Yellow or red disease caused by parasitic nematode is to blame for the falling figures for patchouli essential oil production. This type of nematode is wide in range from Pratylenchus spp. (Pratylenchus coffeae and Pratylenchus brachyurus) which could wound the plant, Meloidogyne spp. (Meloidogyne incognita and Meloidogyne hapla) causing pustules on the plant, to the borer nematode called Radopholus similis [2].

Endoparasite such as nematode Pratylenchus spp., which widely spreads in Indonesia, massively infects patchouli. Despite some attempts such as introduction of nematicide, technical culture, and resistant cultivar, the results gained were not as expected. Although the

\footnotetext{
*Corresponding author:

Cecep Subarjah

Directorate General of Estate, Ministry of Agriculture

Jalan Harsono RM No.3, Jakarta 12550, Indonesia

E-mail: cecep_subarjah@yahoo.co.id
}

use of nematicide could help increase the productivity of plant up to $25 \%$, the intensity of the application could negatively affect the quality of patchouli oil, environment, balance of ecosystems, and human health [3]. Seeing this fact, it is perceived that more organic steps need to be taken into account, one of which is by using compost [1]. This research was conducted to investigate the effects of compost fertilization on the development of population of nematode Pratylenchus sp. and yield of patchouli oil.

\section{MATERIALS AND METHODS}

The research was conducted in research field and Nematology Laboratory, Department of Pest and Plant Diseases, Faculty of Agriculture, Brawijaya University from October 2014 to April 2015. Prior to the research, growing media, nematode multiplication for inocula-

\section{How to cite:}

Subarjah C, Himawan T, Puspitarini RD (2016) Effects of

compost on nematode Pratylenchus sp. (Tylenchida:

Pratylenchidae) population in patchouli. J. Trop. Life. Science

6 (2): $101-106$. 
tion, and plant samples were prepared.

\section{Preparing growing media}

Soil used in this research was obtained from Jatikerto Village, Kromengan District, Malang Regency. Soil was sterilised with formalin (4\%) in anaerobic condition for three days. The sterilised soil was then transferred into polybags, each of which was filled with $5 \mathrm{~kg}$ soil. When ready, these polybags served as growing media for plants during the experiment.

\section{Preparation and multiplication of nematode}

Before inoculum was multiplied, two patchouli plant samples in polybags were prepared. Nematode Pratylenchus sp. inoculum was isolated from soil and root of coffee tree infested with nematode Pratylenchus sp. in Kadudampit District, Sukabumi Regency, East Java. The nematode was then extracted by using Baermann funnel [4], where 5 funnels would be required for root and soil sample. The soil and root were cleaned from any debris before the root was sliced off as long as $0.5-1 \mathrm{~cm}$ and weighed to obtain $10 \mathrm{~g}$ for a sample and $100 \mathrm{~g}$ for soil sample. Separately, the funnels were prepared by placing tissue on top of wire screen into each of the funnel. Each prepared sample was then placed into each funnel and watered. After 24 hours, the extract was obtained and transferred into bottles. The suspension with nematodes was poured into petri dish. The nematodes were taken by using inoculating needle and transferred onto a piece of glass that had been given a drop of glycerin formal fixative solution. Next, the glass was covered for observation and morphological identification. When the identification result showed the presence of Pratylenchus sp., the nematode was to be multiplied by pouring the suspension around the patchouli.

\section{Plant sample preparation for experiment}

The Patchouli was obtained from the nursery located in Kesamben District, Blitar Regency. It was multiplied by applying shoot-cutting taken from young but woody branches of trees with the length of 10-20 $\mathrm{cm}$, and it was then planted in prepared sand. When it was 1.5 month old and turned into a seed, it was ready to be transferred into the prepared polybags, where each was planted with one seed of patchouli, and $31 \mathrm{~g}$ compost was applied when planting.

\section{Effects of compost on population of nematode Praty- lenchus sp.}

This research employed Completely Randomised
Design (CRD) which comprised 6 stages of initial population of nematodes: $0,100,200,300,400$, and 500 nematodes and two growing media such as soil with and without compost. The initial numbers of population of nematodes and growing media were combined and 12 treatments were obtained. Each treatment was replicated three times which made up 36 treatments in total. The treatments tested are as follows:

$$
\begin{array}{ll}
\text { A } & : 0 \text { nematode + soil } \\
\text { B } & : 0 \text { nematode + soil + compost } \\
\text { C } & : 100 \text { nematodes + soil } \\
\text { D } & : 100 \text { nematodes + soil + compost } \\
\text { E } & : 200 \text { nematodes + soil } \\
\text { F } & : 200 \text { nematodes + soil + compost } \\
\text { G } & : 300 \text { nematodes + soil } \\
\text { H } & : 300 \text { nematodes + soil + compost } \\
\text { I } & : 400 \text { nematodes + soil } \\
\text { J } & : 400 \text { nematodes + soil + compost } \\
\text { K } & : 500 \text { nematodes + soil } \\
\text { L } & : 500 \text { nematodes + soil + compost }
\end{array}
$$

Pratylenchus sp. was prepared from extract obtained from the root of coffee tree infested with the nematodes, while the multiplication was obtained by using Baermann funnel method as explained above. The extract in the form of suspension was transferred into a bottle before it was poured into Petri dish. From the Petri dish, the nematodes were taken by using inoculating needle and counted with hand counter. The nematodes would need to be categorized by their number of population: 100, 200, 300, 400, and 500 before they were placed on petri dishes separated based on the population number. Moreover, the counted nematodes were transferred into bottles also based on their category of population. Suspension with nematodes was poured around the ten-day-after-planting patchouli with the distance of about $5 \mathrm{~cm}$ from the plant and 3 $\mathrm{cm}$ in depth. This experimental plant was taken care of by weeding, tilling, controlling pest, and regular watering.

\section{Total oil}

Number of patchouli oil is done by steam distillation method using patchouli oil distillation equipment in Toxicology Laboratory, Department of Plant Pest, Brawijaya University.

\section{Yield loss}

To determine the yield losses due to nematode attttack calculated using the formula Chiarappa (1971 in 
Rival, 2006):

$$
\mathrm{Y}=\mathrm{X}_{0}-\mathrm{X}_{100, \ldots, 500}
$$

$\mathrm{Y} \quad$ : yield loss

$\mathrm{X}_{0} \quad$ : result of the control plants

$\mathrm{X}_{100, \ldots, 500} \quad$ : result in plants inoculated at various treatment initial population of nematodes

To obtain the percentage reduction in yield, is then calculated by the formula Harappa (1971 in Rival, 2006):

$$
\mathrm{Z}=\left(\mathrm{X} \_0-\mathrm{X} \_(100, \ldots, 500)\right) / \mathrm{X} \_0 \times 100 \%
$$

$$
\begin{array}{ll}
\mathrm{Z} & : \text { percentage of yield loss } \\
\mathrm{X}_{0} & : \text { heavy on control plants } \\
\mathrm{X}_{100, \ldots, 500} & : \text { weight in plants inoculated at various treatment } \\
& \text { initial population of nematodes }
\end{array}
$$

\section{Percentage of suppression}

To determine the percentage of suppression is calculated by the number of nematodes in the media without the compost reduced by the number of nematodes in the media with compost divided by the number of nematodes in the media without compost multiplied by one hundred percent.

\section{Statistic analysis}

Observational data obtained were analyzed by analysis of variance (F test) at 5\% level to determine the effffect of treatment. If the result is significantly different then continued with Duncan Multiple Range Test at the $5 \%$ significance level to determine differences between treatments.

\section{RESULTS AND DISCUSSION}

\section{Number of nematodes Pratylenchus sp. in root and} soil

Averagely, the number of Pratylenchus sp. in root given treatment was significantly higher than that of control. The average population of nematodes Pratylenchus sp. was found higher (69.33) in the treatment of 500 nematodes + soil (Table 1 ).

The addition of compost was able to suppress the population of Pratylenchus sp. with the percentage ranging from 58.93 to $67.31 \%$. The compost application seemed to be able to increase the activity of antagonistic fungal agents capable of colonizing plant roots, creating barrier for nematodes to penetrating the root tissues. As a result, their access to wound the plants was reduced. According to Harni and Mustika (2000), suggested that organic matters applied to soil could suppress the population of Pratylenchus sp. in both root of patchouli and soil [5]. This application was also believed to be able to reduce the attack of nematode. This was due to the fact that the decomposed organic matters were toxic to nematode in addition to their ability to increase the activity of antagonistic microorganisms in soil.

Based on the identification, Trichoderma sp. was found dominant in compost given to treatments, with the population $2.1 \times 10^{4} \mathrm{propogul} / \mathrm{g}$. According to Olabiyi (2013), stated that the use of compost composed of dead leaves mixed with Trichoderma harzianum Persoon significantly reduced the population of nematode Pratylenchus sp., Xiphinema sp., and Meloidogyne sp. with its parasitic ability [6], Trichoderma sp. was capable of directly reducing the possibility of disease and indirectly competing for space and nutrients.

The content of Trichoderma sp. in compost is believed to be able to produce enzymes and some secondary metabolite compounds which could suppress the population growth of the nematode and increase plant resistance to nematode attack. Those enzymes are able to control nematode [7]. Trichoderma sp. produces enzyme such as protease and chitinase which can degrade and rapture the egg's wall of nematodes. Besides, this fungal agent could also produce other enzymes such as peroxide, polyphenol oxidase, phenylalanine ammonia lyase which could induce systematic resistance of a plant. Sharon et al. (2001), confirmed that all strains of Trichoderma showed potential to colonize egg and second stage juvenile of Meloidogyne javanica in sterile in vitro test and to penetrate egg mass [8]. In short, the role of protease from Trichoderma spp. performs similar function to nematicide.

The increase in population of Pratylenchus sp. In $10 \mathrm{~g}$ root of patchouli and $100 \mathrm{~g}$ soil was in line with the increase of stage in initial population of nematode (Fig. 1). The increasing number of the nematodes in 10 $\mathrm{g}$ root and $100 \mathrm{~g}$ soil without compost was relatively higher than that in $10 \mathrm{~g}$ root and $100 \mathrm{~g}$ soil with compost.

The number of Pratylenchus sp. in root of patchouli planted in the medium without compost showed relatively higher increase than that in root planted in the medium added with compost. The average number of nematodes in root planted in soil added with compost was lower than that in root planted in just soil. According to Yedidia et al. (2000), asserted that Trichoderma sp. was potential to directly enhance plant growth and suppress the growth of pathogens by 
Table 1. The average population of Nematodes Pratylenchus sp. in $10 \mathrm{~g}$ root and $100 \mathrm{~g}$ soil with initial population of nematodes

\begin{tabular}{|c|c|c|c|c|}
\hline Treatment & $\begin{array}{c}\text { Number of Nematodes in } \\
10 \mathrm{~g} \text { root }(x \pm S D)\end{array}$ & Suppression (\%) & $\begin{array}{c}\text { Number of Nematodes in } \\
100 \mathrm{~g} \text { soil }(x \pm S D)\end{array}$ & Suppression (\%) \\
\hline$\overline{0 \text { Nematode + Soil }}$ & $0.00 \pm 0.00^{\mathrm{d}}$ & & $0.00 \pm 0.00^{c}$ & \\
\hline 0 Nematode + Soil + Compost & $0.00 \pm 0.00^{\mathrm{d}}$ & & $0.00 \pm 0.00^{\mathrm{c}}$ & \\
\hline 100 Nematodes + Soil & $37.33 \pm 8.05^{\mathrm{abcd}}$ & & $46.33 \pm 3.68^{\mathrm{abc}}$ & \\
\hline 100 Nematodes + Soil + Compost & $15.33 \pm 1.25^{\mathrm{bcd}}$ & 58.93 & $23.67 \pm 2.05^{\mathrm{bc}}$ & 48.92 \\
\hline 200 Nematodes + Soil & $31.33 \pm 9.28^{\mathrm{abcd}}$ & & $54.00 \pm 9.27^{\mathrm{ab}}$ & \\
\hline 200 Nematodes + Soil + Compost & $12.67 \pm 3.86^{\mathrm{cd}}$ & 59.57 & $32.00 \pm 2.94^{\mathrm{bc}}$ & 40.74 \\
\hline 300 Nematodes + Soil & $49.33 \pm 9.84^{\mathrm{abc}}$ & & $67.67 \pm 10.65^{\mathrm{ab}}$ & \\
\hline 300 Nematodes + Soil + Compost & $16.67 \pm 2.05^{\mathrm{bcd}}$ & 66.21 & $34.00 \pm 5.72^{\mathrm{bc}}$ & 49.75 \\
\hline 400 Nematodes + Soil & $57.33 \pm 21.45^{\mathrm{ab}}$ & & $72.33 \pm 4.99^{\mathrm{ab}}$ & \\
\hline 400 Nematodes + Soil + Compost & $19.67 \pm 1.70^{\mathrm{bcd}}$ & 65.70 & $32.00 \pm 2.45^{\mathrm{bc}}$ & 55.76 \\
\hline 500 Nematodes + Soil & $69.33 \pm 2.62^{\mathrm{a}}$ & & $90.67 \pm 5.31^{\mathrm{a}}$ & \\
\hline 500 Nematodes + Soil + Compost & $22.67 \pm 3.40^{\mathrm{bcd}}$ & 67.31 & $37.00 \pm 1.63^{\mathrm{bc}}$ & 59.19 \\
\hline
\end{tabular}

Table 2. Average amount of patchouli oil and yield loss in several treatments with initial population of nematodes

\begin{tabular}{lccc}
\hline \multicolumn{1}{c}{ Treatment } & $\begin{array}{c}\text { Amount of patchouli oil }(g / 25 g \\
\text { dry terna) }(x \pm S D)\end{array}$ & $\begin{array}{c}\text { Oil yield loss } \\
(g / 25 g \text { dry terna })(x \pm S D)\end{array}$ & Yield loss in percentage (\%) \\
\hline 0 Nematode + Soil & $1.15 \pm 0.12^{\mathrm{ab}}$ & $0.00 \pm 0.00^{\mathrm{c}}$ & 0.00 \\
0 Nematode + Soil + Compost & $1.57 \pm 0.05^{\mathrm{a}}$ & $0.00 \pm 0.00^{\mathrm{c}}$ & 0.00 \\
100 Nematodes + Soil & $0.95 \pm 0.06^{\mathrm{abc}}$ & $0.20 \pm 0.17^{\mathrm{bc}}$ & 15.85 \\
100 Nematodes + Soil + Compost & $1.27 \pm 0.05^{\mathrm{a}}$ & $0.30 \pm 0.02^{\mathrm{bc}}$ & 18.93 \\
200 Nematodes + Soil & $0.92 \pm 0.03^{\mathrm{abc}}$ & $0.22 \pm 0.09^{\mathrm{bc}}$ & 18.91 \\
200 Nematodes + Soil + Compost & $1.14 \pm 0.05^{\mathrm{ab}}$ & $0.42 \pm 0.07^{\mathrm{abc}}$ & 26.95 \\
300 Nematodes + Soil & $0.42 \pm 0.11^{\mathrm{bcd}}$ & $0.73 \pm 0.23^{\mathrm{ab}}$ & 62.24 \\
300 Nematodes + Soil + Compost & $0.88 \pm 0.05^{\mathrm{abcd}}$ & $0.69 \pm 0.10^{\mathrm{abc}}$ & 43.90 \\
400 Nematodes + Soil & $0.28 \pm 0.16^{\mathrm{cd}}$ & $0.86 \pm 0.08^{\mathrm{ab}}$ & 76.34 \\
400 Nematodes + Soil + Compost & $0.79 \pm 0.03^{\mathrm{abcd}}$ & $0.77 \pm 0.04^{\mathrm{ab}}$ & 49.34 \\
500 Nematodes + Soil & $0.07 \pm 0.04^{\mathrm{d}}$ & $1.08 \pm 0.08^{\mathrm{a}}$ & 94.16 \\
500 Nematodes + Soil + compost & $0.77 \pm 0.11^{\mathrm{abcd}}$ & $0.80 \pm 0.16^{\mathrm{ab}}$ & 50.80 \\
\hline
\end{tabular}

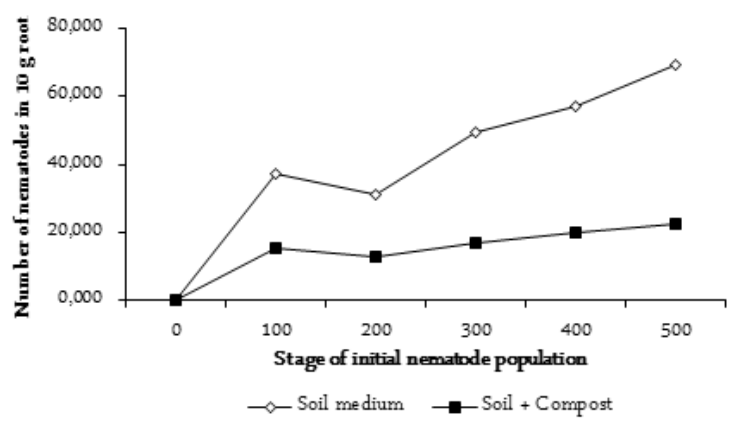

(a)

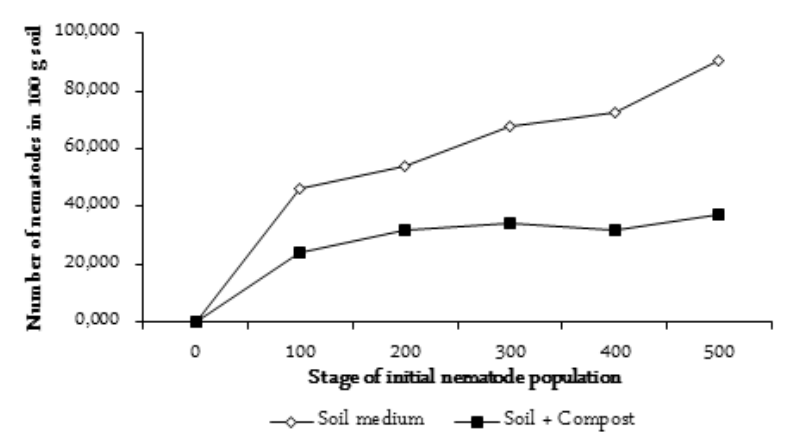

(b)

Figure 1. Correlation between stages of initial population of nematodes and average number of Pratylenchus sp. in $10 \mathrm{~g}$ root of patchouli in two planting media (a) and in $100 \mathrm{~g}$ soil in two planting media (b) 
colonizing the area of rhizosphere and invading superficial layer of cortex of root, which reduced chambers for pathogens [9].

Similarly, the average number of Pratylenchus sp. In $100 \mathrm{~g}$ soil in several treatments was significantly higher than that of control. The highest average number of Pratylenchus sp. (90.67) was found in plant growing in soil +500 nematodes.

Addition of compost in treatments could suppress the population growth of nematode Pratylenchus sp. In $100 \mathrm{~g}$ soil with suppression percentage ranging from $40.74-59.19 \%$. The compost added in this experiment seemed able to increase organic content in soil and increase the population of antagonistic fungal agent such as Trichoderma sp. which could reduce the number of nematodes in soil. Dropkin (1996), stated that organic matters could be used to increase the population of antagonistic fungal agents, for compounds were released during the process of decomposition [10]. Decomposing remnants from plant tissues give off ammonia, salts, and simple organic acids such as acetic acid, propionate, and butyrate, which are toxic to nematodes. Organic matters added will be decomposed by microorganisms, forming and releasing toxic compounds which kill nematodes. According Dunn (1994), agreed that decomposition of organic matters served as nutrients to soil microbes such as fungi, Actynomycetes, and bacteria [11]. The increasing number of natural enemies for parasitic nematodes is able to control the population of nematodes naturally.

In addition, some secondary metabolites emitted by Trichoderma sp. were also toxic to nematodes' eggs, meaning that Trichoderma sp. also had potential to suppress the hatching. Stoppacher et al. (2010), reported that Trichoderma spp. was capable of producing volatile compound from its secondary metabolite [12]. According to Wheatley et al. (1997) and Yang et al. (2012), asserted that volatile compound determined the habitat of organisms. Volatile compound produced by Trichoderma sp. comprises 2-propanones, 2-methyl-1butanols, heptane, octane and decane with their antimicrobial potential. Some other compounds produced also include $1 \beta$-vinylcyclopentane- $1 \alpha$, 6-pentyl- $2 \mathrm{H}$ pyran-2-one, and 4-(2-hydroxyethyl) phenol, which are volatile and have potential to kill nematodes [13, 14].

\section{Amount of oil and yield loss}

The average amount of oil produced in several treatments was significantly lower than that in control group. The amount produced ranged from $0.07-1.57$ g/25 g dry terna. Each plant infested with nematodes of different initial population caused a decrease in the amount of oil yielded (Table 2).

The average amount of patchouli oil in plants with compost was relatively higher than that of plants without compost, so that the addition of compost positively influenced the increase in the amount of oil yielded.

The plant condition which was less resistant to the attack of the nematode seemed to affect the decrease of oil content yielded. It was obvious when the amount of oil kept decreasing as the initial of nematode population was increasing. Harni (1995), stated that the attttack of nematode could cause damage on plant and de crease up to $85 \%$ [15].

This decrease was believed to be caused by the damaged root, restricting it from absorbing sufficient nutrients and mineral which were required to help the plant grow and form oil content in patchouli. They were also needed in plant to form chlorophyll. When these elements are not presence, nitrogen $(\mathrm{N})$, magnesium $(\mathrm{Mg})$ and iron $(\mathrm{Fe})$ will surely cause chlorosis.

The average oil yield loss in each treatment was higher than that of control, ranging from $0.20-1.08 \mathrm{~g}$ (15.85-94.16\%). Harni (1995), reported that this loss due to nematode could reduce the yield up to $85 \%$ [15].

The table shows that the lowest yield loss $(0.20 \mathrm{~g})$ was obtained with the initial population of 100 nematodes + soil, while the highest $(1.08 \mathrm{~g})$ was with initial population of 500 nematodes + soil. The compost added in the treatment with initial population of 300500 nematodes could reduce yield loss as much as $0.04-$ $0.28 \mathrm{~g}(18.34-43.36 \%)$.

\section{CONCLUSION}

Compost could suppress the population of nematode Pratylenchus sp. as much as $58.93-67.31 \%$ and $40.74-59.19 \%$ in $10 \mathrm{~g}$ root of patchouli and in $100 \mathrm{~g}$ soil in each treatment, respectively. The addition of compost in the treatments positively affected the increase in the amount of patchouli oil yielded, and it helped reduce the loss up to $18.34-43.36 \%$.

\section{ACKNOWLEDGMENT}

\section{REFERENCES}

1. Harni R, Nuryani Y (2006) Strategies in controlling parasitic nematode on patchouli (in Indonesian). Balai Penelitian Tanaman Rempah dan Obat. Bogor.

2. Wahyuno D, Hartati SY, Djiwanti SR et al (2012) Crucial diseases in patchouli and control (in Indonesian). Bogor, 
Balittro.

3. Harni R, Mustika I, Hobir (2007) Resistance of several numbers and varieties of patchouli to nematode Pratylencus brachyurus (Godfrey) (in Indonesian). Buletin Balittro 18 (1): 67-72.

4. Sriwati R (1999) Resistance of several patchouli cultivars (Pogostemon cablin Benth.) to Pratylenchus brachyurus (in Indonesian) (Godfrey) Filipjev. \& Stekhoven. Master Thesis. Bogor Agriculture University.

5. Harni R, Mustika I (2000) Effects of infested Pratylenchus brachyurus, Meloidogyne incognita, and Radopholus similis on patchouli (in Indonesian). Buletin Balittro 11:47-54.

6. Olabiyi TI, Gbadamosi AR (2013) The effect of four compost soil amendments based on Trichoderma harzianum on nematode pest of sesame. International Journal of Agronomy and Plant Production 4 (5): 3859-3863.

7. Sahebani N, Hadavi N (2008) Biological control of the root-knot nematode Meloidogyne javanica by Trichoderma harzianum. Soil Biology and Biochemistry 40: 2016-2020.

8. Sharon E, Bar EM, Chet I et al (2001) Biological control of the root-knot nematode Meloidogyne javanica by Trichoderma harzianum. Journal Phytopathology 91: 687693.

9. Yedidia I, Benhamou N, Kapulnik Y et al (2000) Induc- tion and accumulation of $\mathrm{PR}$ proteins activity during early stages of root colonization by the mycoparasite Trichoderma harzianum Strain T-203. Plant Physiology Biochemistry 38: 863-873.

10. Dropkin VH (1996) Introduction to plant nematology (translated version) (in Indonesian). Yogyakarta, Gadjah Mada University Press.

11. Crow WT, Dunn RA (1994) Soil organic matter, green manures, and cover for nematode management. University of Florida.

12. Stoppacher N, Kluger B, Zeilinger S et al (2010) Identication and profiling of volatile metabolites of the biocontrol fungus Trichoderma atroviride by HS-SPME-GC-MS. Journal of Microbiological Methods 81: 187-193.

13. Wheatley R, Hackett C, Bruce A et al (1997) Effect of substrate composition on production of volatile organic compounds from Trichoderma spp. inhibitory to wood decay fungi. International Biodeterioration and Biodegradation 39 (2,3): 199-205.

14. Yang Z, Yu Z, Lei L et al (2012) Nematicidal effect of volatiles produced by Trichoderma sp. Journal of Asia-Pacific Entomology 15: 647-650.

15. Harni R (1995) Nematode attack on spices and herbal plants (Indonesian). Media Komunikasi Penelitian dan Pengembangan Tanaman Industri 15. 